\title{
Pembelajaran Tematik Terpadu Melalui Pendekatan Saintifik Berbasis Lingkungan
}

Nida Fitri Yansyah', Salati Asmahasanah², Hilman Hakiem ${ }^{3}$

1) Pendidikan Guru Madrasah Ibtidaiyah; Universitas Ibn Khaldun Bogor; Bogor; nidafitri2@gmail.com

2) Pendidikan Guru Madrasah Ibtidaiyah ; Universitas Ibn Khaldun Bogor; Bogor; salati@fai.uika-bogor.ac.id

3) Ekonomi Syariah; Universitas Ibn Khaldun Bogor; Bogor; hilman@uikabogor.ac.id

Abstrak. Tujuan penelitian ini adalah untuk mengetahui proses pembelajaran dan pelaksanaan pembelajaran tematik serta meningkatkan hasil pembelajaran tematik melalui penerapan metode outdoor study berbasis scientific learning. Penelitian ini dilaksanakan di SD Kreativa Kota Bogor tahun ajaran 2018/2019. Subjek penelitian dilaksanakan pada kelas IVB yang terdiri dari 21 siswa. Penelitian ini menggunakan Penelitian Tindakan Kelas (PTK) yang terdiri dari empat tahapan, yaitu perencanaan, pelaksanaan, observasi, dan refleksi. Hasil penelitian menunjukkan bahwa dengan penerapan metode outdoor study berbasis scientific learning dapat meningkatkan hasil belajar siswa pada pembelajaran tematik tema 8 subtema 3. Hal tersebut dapat terlihat dari pencapaian hasil belajar yang dilakukan pada setiap siklusnya serta lembar observasi aktivitas pada pembelajaran tematik yang dilakukan oleh guru dan siswa yang mengalami peningkatan pada setiap siklusnya. Hasil belajar rata-rata keseluruhan siswa yang diperoleh pada siklus I mencapai nilai rata-rata sebesar 70,48 dan meningkat pada hasil belajar siklus II yaitu mencapai nilai rata-rata sebesar 84,38 . Adapun hasil observasi aktivitas guru pada siklus I yaitu $70 \%$ dan pada siklus II yaitu $83,75 \%$. Sedangkan observasi aktivitas siswa pada pembelajaran tematik dalam kegiatan belajar mengajar mengalami peningkatan setiap siklusnya yaitu pada siklus I mencapai $67,85 \%$ dan siklus II yaitu $82,14 \%$. Dengan demikian, menggunakan metode outdoor study berbasis scientific learning dapat meningkatkan hasil pembelajaran tematik pada siswa kelas IV SD Kreativa Bogor.

Kata Kunci : Pembelajaran Tematik, Outdoor Study, Scientific Learning

Abstract. The purpose of this study was to find out the learning process and the implementation of thematic learning and improve the results of thematic learning through the application of outdoor study methods based on scientific learning. This research was conducted at Kreativa Elementary School, Bogor City, 2018/2019 academic year. The research subjects were carried out in class IVB consisting of 21 students. This study used Classroom Action Research (CAR) which consists of four stages, which are planning, implementation, observation, and reflection. The results of the study showed that applying

Caruban : Jurnal Ilmiah Pendidikan Dasar 2(1), 40-52, Januari 2019

p-ISSN 2615-1391, e-ISSN 2620-3219 @Prodi PGSD Universitas Swadaya Gunung Jati 
the outdoor study method based on scientific learning could improve student learning outcomes in thematic learning theme 8 sub-theme 3. This result could be seen from the achievement of learning outcomes carried out in each cycle as well as the observation sheet of activities on thematic learning carried out by teachers and students who experienced an increase in each cycle. The average overall learning outcomes of students obtained in the first cycle reached an average value of 70,48 and increased in the learning outcomes of the second cycle which reached an average value of 84,38 . The results of the observation of teacher activities in the first cycle were $70 \%$ and in the second cycle $83.75 \%$. While the observation of student activities in thematic learning in teaching and learning activities experienced an increase in each cycle, namely in the first cycle reached $67.85 \%$ and the second cycle was $82.14 \%$. Thus, using the outdoor study method based on scientific learning can improve thematic learning outcomes for fourth grade students at SD Kreativa Bogor.

Keywords: Thematic Learning, Outdoor Study, Scientific Learning

\section{Pendahuluan}

Pendidikan adalah aktivitasi semua potensi dasar manusia melalui interaksi antara manusia dewasa dengan yang belum dewasa. Pendidikan merupakan proses permatabatan manusia menuju puncak optimasi potensi kognitif, afektif, dan psikomotorik yang dimilikinya. Pendidikan dapat diartikan sebagai proses membimbing, melatih, dan memandu manusia. Menurut Brubacher (dalam Danim, 2013: 2) "pendidikan sebagai suatu proses pengembangan potensi dasar manusia yang berkaitan dengan moral, intelektual, dan jasmaninya untuk mencapai tujuan hidup dalam kerangka sistem sosial".

Masalah yang dihadapi dalam dunia pendidikan dasar adalah masalah lemahnya metode maupun model pembelajaran. Proses pembelajaran siswa kurang didorong untuk mengembangkan keterampilan berpikir. Proses pembelajaran di dalam kelas diarahkan kepada kemampuan siswa untuk menghafal informasi dan siswa terbiasa mengingat informasi tanpa berusaha untuk menghubungkannya dalam kehidupan sehari-hari. Akibatnya siswa hanya mengetahui informasi itu tanpa mengetahui pemahamannya.

Pada kurikulum 2013 sekolah dasar di Indonesia sudah disajikan dalam pembelajaran tematik, termasuk di SD Kreativa Kota Bogor. Hasil observasi dengan guru kelas IV B ini menyatakan bahwa masih ada siswa yang mendapatkan nilai dibawah kriteria ketuntasan minimal (KKM)

Caruban : Jurnal Ilmiah Pendidikan Dasar 2(1), 40-52, Januari 2019

p-ISSN 2615-1391, e-ISSN 2620-3219 @Prodi PGSD Universitas Swadaya Gunung Jati 
dengan nilai KKM 70. Dengan adanya pembelajaran tematik siswa terlihat jelas karakter dan bakatnya lebih muncul, namun siswa kurang fokus dalam materi pelajaran. Tetapi pembelajaran tematik di SD Kreativa ini lebih senang di kelas (dalam ruangan) sehingga siswa merasa jenuh. Maka dari itu peneliti ingin membangun siswa untuk fokus dalam menerima materi, agar siswa akan mendapatkan hasil belajar yang baik.

Banyak sekali metode pembelajaran yang dapat digunakan dalam proses belajar mengajar, salah satunya adalah metode outdoor study. Metode mengajar di luar kelas dapat dipahami sebagai suatu kegiatan menyampaikan pelajaran di luar kelas, sehingga kegiatan atau aktivitas belajar-mengajar berlangsung di luar kelas atau di alam bebas (lingkungan). Menurut Salati Asmahasanah, dkk (2018: 11) lingkungan menyediakan rangsangan (stimulus) terhadap individu dan sebaliknya individu memberikan respons terhadap lingkungan. Dalam proses interaksi itu dapat terjadi perubahan diri. Pendapat lain mengatakan betapa pentingnya lingkungan sebagai media belajar. Hal tersebut menunjukkan bahwa lingkungan sangat penting pengaruhnya terhadap perolehan siswa akan pelajaran yang dipelajarinya.

Menurut Maheni dalam Salati Asmahasanah (2018: 241-248):

"That the use of school gardens makes learning more meaningful because students are involved directly so that students can construct their own knowledge, that school gardens can be used as natural laboratories in natural science learning, one of which can improve students knowledge of the scientific name of plants".

Pemanfaatan lingkungan sekolah dapat menambah aspek kegembiraan dan kesenangan bagi para siswa, sebagaimana layaknya seorang anak yang sedang bermain di alam bebas. Situasi ini akan mendukung efektivitas proses pembelajaran, khususnya bagi anak. Karena melalui pembelajaran outdoor study siswa dapat belajar sesuatu yang konkrit atau nyata yang dapat disajikan dalam bentuk pengamatan, observasi, diskusi atau bermain. Desain pembelajaran tematik berbasis outdoor study ini dapat dijadikan alternatif oleh guru dalam melakukan proses pembelajaran yang mengembangkan rasa ingin tahu yang dimiliki siswa dan dalam proses pembelajaran yang memberikan pengalaman langsung bagi siswa.

Dalam kurikulum 2013 mengusung tema yang menghasilkan insan Indonesia yang produktif, kreatif, inovatif, dan afektif (berkarakter), melalui 
penguatan sikap, keterampilan, dan pengetahuan secara terintegrasi. Untuk merealisasikan tema tersebut diperlukan perubahan, terutama dalam proses dan penilaian pembelajaran, yang harus lebih diorientasikan kepada siswa. Proses pembelajaran diselenggarakan secara interaktif, inspiratif, menyenangkan, menantang, memotivasi siswa untuk berpartisipasi aktif, serta memberikan ruang yang cukup bagi perkembangan fisik serta psikologis siswa. Untuk itu setiap satuan pendidikan harus melakukan perencanaan pembelajaran, pelaksanaan proses pembelajaran serta penilaian proses pembelajaran (Mulyasa, 2014: 72-74).

Pembelajaran tematik sebagai model pembelajaran termasuk salah satu tipe atau jenis daripada model pembelajaran terpadu. Istilah pembelajaran tematik pada dasarnya adalah model pembelajaran terpadu yang menggunakan tema untuk mengaitkan beberapa mata pelajaran sehingga dapat memberikan pengalaman bermakna kepada siswa (Trianto, 2011: 147).

Untuk dapat mengimplementasikan pembelajaran tematik dengan maksimal maka guru harus menggunakan pendekatan atau model-model yang efektif dan sesuai dengan pembelajaran. Salah satu pendekatan pembelajaran yang sesuai adalah pendekatan scientific. Menurut Abdul Majid (2017: 80-211), pendekatan scientific menekankan pada pentingnya kolaborasi dan kerja sama di antara peserta didik dalam menyelesaikan setiap permasalahan dalam pembelajaran. Adapun penerapan pendekatan saintifik dalam pembelajaran melibatkan keterampilan proses, seperti mengamati, mengklasifikasi, mengukur, meramalkan, menjelaskan, dan menyimpulkan. Dalam melaksanakan proses-proses tersebut, bantuan seorang guru sangat diperlukan. Akan tetapi, bantuan guru tersebut harus semakin berkurang dengan semakin tingginya kelas siswa (Hosnan, 2014:34).

Keberhasilan penerapan metode outdoor study berbasis scientific learning untuk meningkatkan hasil pembelajaran tematik pernah diterapkan oleh peneliti terdahulu. Penelitian yang dilakukan oleh Hindira Wardani (2017) yang berjudul "Penerapan Metode Outdoor Study Dalam Meningkatkan Motivasi Belajar Peserta Didik Kelas IV Pada Mata Pelajaran Matematika di Madrasah Ibtidaiyah Negeri 10 Bandar Lampung". Penelitian ini memperoleh hasil bahwa menggunakan metode outdoor study lebih baik dari pada kelas kontrol yang menggunakan pembelajaran konvensional. Berdasarkan hal tersebut maka dalam penelitian ini akan dianalisis 
peningkatan hasil belajar siswa pada pembelajaran tematik melalui metode outdoor study berbasis scientific learning.

\section{Metode Penelitian}

Penelitian ini menggunaan jenis Penelitian Tindakan Kelas Penelitian. Menurut Ebbut (dalam Kunandar, 2016: 45) penelitian tindakan adalah kajian sistemik dari upaya perbaikan pelaksanaan praktik pendidikan oleh sekelompok guru dengan melakukan tindakan-tindakan dalam pembelajaran, berdasarkan refleksi mereka mengenai hasil dari tindakantindakan Penelitian ini menggunakan jens penelitian tindakan kelas dengan mengadopsi model Kemmis dan Mc. Taggrat. Setiap siklus terdiri dari empat tahapan yaitu perencanaan (planning), pelaksanaan (acting), observasi (observing), dan refleksi (reflecting) (Tampubolon, 2014: 27).

Penelitian ini dilaksanakan pada semester II tahun ajaran 2018/2019 tepatnya pada bulan Maret-April 2019 di SD Kreativa Bogor Kelurahan Sukadamai Kecamatan Tanah Sareal. Subjek dalam penelitian ini adalah siswa kelas IV B SD Kreativa sejumlah 21 siswa dengan 8 siswa laki-laki dan 13 siswa perempuan.

Adapun pengumpulan data pada penelitian ini menggunakan 1) Tes, tes ini dilakukan dengan tujuan untuk mengetahui peningkatan hasil belajar, tes juga merupakan salah satu rangkaian kegiatan dalam melihat hasil. 2) Observasi, observasi digunakan untuk mengamati dan mengumpulkan data tentang aktivitas guru dan aktivitas siswa selama proses pembelajaran. 3) Wawancara, wawancara digunakan untuk mendapatkan data yang dibutuhkan dalam penyusunan penelitian. 4) Dokumentasi, dokumentasi ini dapat digunakan untuk membantu menggambarkan apa yang terjadi dikelas ketika proses pembelajaran.

Penentuan ketuntasan belajar siswa menurut dihitung dengan menggunakan rumus :

$$
X=\frac{\text { Jumlah siswa diatas KKM }}{\text { jumlah seluruh siswa }} \times 100 \%
$$

Konversi nilai hasil penelitian untuk menganalisis dan menginterpretasi data dapat menggunakan kategori keberhasilan tindakan sebagai berikut (Tampubolon, 2014: 55) :

$81 \%-100 \%=$ sangat baik

Caruban : Jurnal Ilmiah Pendidikan Dasar 2(1), 40-52, Januari 2019

p-ISSN 2615-1391, e-ISSN 2620-3219 @Prodi PGSD Universitas Swadaya Gunung Jati 


$$
\begin{array}{ll}
61 \%-80 \% & =\text { baik } \\
41 \%-60 \% & =\text { cukup } \\
21 \%-40 \% & =\text { kurang baik } \\
0 \%-20 \% & =\text { sangat tidak baik }
\end{array}
$$

Anas Sudijono (2017: 43) menyatakan rumus yang digunakan untuk analisis lembar observasi aktivitas guu dan siswa yaitu :

$$
\mathrm{p}=\frac{f}{N} \times 100 \%
$$

Keterangan :

$\mathrm{P}=$ persentase

$\mathrm{f}=$ skor yang diperoleh

$\mathrm{N}$ = jumlah skor maksimum

\section{Hasil Penelitian dan Pembahasan}

Pembahasan hasil penelitian ini akan diuraikan berdasan dari setiap siklus tindakan yang dilakukan sebagai berikut:

\section{a. Prasiklus}

Sebelum diadakan penelitian, kondisi kelas IV SD Kreativa Bogor mempunyai nilai di bawah KKM. Rendahnya pencapaian Kriteria Ketuntasan Minimal (KKM) yang dicapai oleh siswa kelas IV SD Kreativa Bogor tidak bisa serta merta diarahkan kepada guru seluruhnya, tetapi masih banyak faktor lain yang bisa dijadikan buruknya pencapaian nilai KKM ini. Pada saat guru kelas IV sedang melakukan proses belajar mengajar di kelas, dalam hal ini penulis melakukan pengamatan ketika siswa sedang belajar. Rata-rata dari mereka mengalami kesulitan dalam mempraktikan apa yang telah disampaikan oleh guru mereka. Kondisi ini memberikan dampak sendiri terhadap pencapaian KKM siswa kelas IV tersebut. Seperti dikatakan sebelumnya dari 21 siswa yang ada, hanya 9 siswa yang memenuhi KKM dengan catatan mereka hanya menerima nilai ambang tuntas saja. Sedangkan 12 siswa diantara mereka mendapatkan nilai di bawah 70 dan tidak tuntas dalam pembelajaran tematik. Artinya hanya $42,86 \%$ sajalah persentase pencapaian KKM.

\section{b. Siklus I}

Penyajian data hasil penelitian berupa hasil pengamatan aktivitas guru dan siswa selama proses pembelajaran berlangsung dan data hasil belajar 
yang diperoleh di akhir siklus penelitian. Pelaksanaan setiap siklus penelitian ini dapat dijelaskan sebagai berikut :

Pada tahap perencanaan ini, untuk mencapai pembelajaran yang diharapkan kegiatan pembelajaran direncanakan secara rinci. Kegiatan tersebut yaitu 1) Menganalisis kurikulum untuk mengetahui kompetensi inti serta kompetensi dasar. Pada tahap ini juga peneliti menentukan indikator pembelajaran, tujuan pembelajaran dan materi yang akan dicapai maupun disampaikan. Analisis yang dilakukan mengacu pada kurikulum 2013 (kurtilas). 2) Menyusun perangkat pembelajaran yaitu silabus pembelajaran dan RPP (Rencana Pelaksanaan Pembelajaran). 3) Menyusun lembar kegiatan siswa yang akan digunakan pada saat proses pembelajaran berlangsung. 4) Menyusun alat evaluasi berupa tes tertulis untuk mengetahui hasil belajar siswa. 5) Merancang lembar observasi yang akan digunakan untuk mengobservasi kegiatan pembelajaran. Peneliti membuat lembar observasi aktivitas guru dan siswa selama proses pembelajaran.

Pelaksanaan tindakan dan observasi penelitian dilaksanakan pada hari senin, 01 April 2019 dengan alokasi waktu 2 x 35 menit. Pada pelaksanaan siklus ini, peneliti melaksanakan pembelajaran tematik sesuai dengan RPP yang telah disusun dengan menggunakan metode outdoor study berbasis scientific learning, dimana kegiatannya dilakukan di halaman sekolah.

Pada kegiatan awal, guru mengawali kegiatan pembelajaran denga mengucapkan salam. Setelah itu guru mengkondisikan kelas dengan mengajak siswa melakukan ice breaking untuk siswa berkonsentrasi sebelum dimulainya pembelajaran. Kemudian dilakukan dengan kegiatan apersepsi tujuannya untuk memacu interaksi antara guru dan siswa serta mengetahui pengetahuan awal yang dimiliki siswa. Pada kegiatan ini terdapat respon positif dari siswa, karena pada saat guru memberikan stimulus berupa pertanyaan, ada sebagian siswa yang menjawab pertanyaan dari guru. Setelah itu guru menyampaikan tujuan pembelajaran.

Guru membahas tema 8 daerah tempat tinggalku subtema 3 pembelajaran 3. Sedangkan pada kegiatan inti pembelajaran meliputi kegiatan mengamati, menanya, mengasosiasi, mengumpulkan informasi, dan mengkomunikasikan. Sebelum melakukan pembelajaran di luar kelas, guru menyebutkan tata tertib ketika melakukan belajar di luar kelas. Guru dan siswa keluar kelas bersama-sama dan mencari tempat yang nyaman untuk melakukan kegiatan proses pembelajaran. 
Kemudian guru memberikan sebuah teks cerita fiksi yang berjudul "Balas Budi Singa". Siswa mengamati sebuah teks tersebut dan membacanya dengan jelas. Setelah semua siswa membaca teks cerita fiksi tersebut, guru memberikan pertanyaan tentang penokohan yang terdapat dalam sebuah teks cerita fiksi tersebut. Selanjutnya guru memberikan materi pembelajaran kepada siswa dengan jelas. Kemudian guru bertanya kepada siswa upaya yang dapat dilakukan terhadap perbedaan karakter serta manfaat. Kemudian guru menjelaskan materi berikutnya.

Selanjutnya guru membagi siswa ke dalam 4 kelompok yang terdiri dari 5-6 siswa secara heterogen. Setelah selesai melakukan pembagian kelompok, guru memberikan LKS (Lembar Kegiatan Siswa) dan menjelaskan cara mengerjakannya. Kemudian guru membimbing kegiatan diskusi siswa. Siswa diminta untuk mengumpulkan informasi dan menyelesaikan LKS tersebut. Setelah selesai, setiap kelompok untuk mengkomunikasikan hasil diskusinya di depan teman-teman semua. Kelompok yang belum membacakan hasilnya diharapkan untuk mendengarkan temannya yang sedang menyampaikan hasil diskusinya.

Pada kegiatan akhir pembelajaran, guru melakukan tes evaluasi terhadap siswa. Pada tes ini setiap siswa menjawab 5 butir soal yang diberikan oleh guru secara individu. Kemudian guru menyimpulkan apa yang telah dipelajari. Guru mengucapkan salam dan menutup pembelajaran dengan mengucapkan hamdalah.

Hasil belajar siswa pada pembelajaran tematik melalui metode outdoor study berbasis scientific learning pada siklus I diperoleh data 11 siswa yang tuntas dalam belajar dan 10 siswa masih belum memenuhi kriteria ketuntasan minimal. Dengan nilai rata-rata yaitu 70,48 dan persentase mencapai 52,38\%. Dari pelaksanaan siklus I tersebut, diperoleh nilai tertinggi yaitu 90 dan nilai terendah yaitu 50 .

Kegiatan observasi pada siklus I dilakukan untuk mengumpulkan data mengenai aktivitas guru maupun siswa dalam proses pembelajaran. Hasil observasi aktivitas guru selama proses pembelajaran mencapai persentase yaitu $70 \%$. Dan hasil observasi aktivitas siswa selama proses pembelajaran berlangsung mencapai persentase yaitu 67,85\%. Adapun refleksi yang terjadi di siklus I salah satunya adalah guru belum mampu membagi waktu dalam proses pembelajaran di luar kelas sehingga tidak sesuai dengan alokasi 
waktu. Maka proses pembelajaran belum dapat dihentikan dan harus ada perbaikan pada siklus II.

\section{c. Siklus II}

Pada pembelajaran siklus II, peneliti menyusun kembali perencanaan berdasarkan refleksi pada siklus I. Peneliti juga merencanakan perbaikan yang akan dilaksanakan pada siklus II. Tahap perencanaan ini, kegiatan yang dilakukan diantara lain yaitu 1) Menganalisis kurikulum untuk mengetahui kompetensi inti serta kompetensi dasar. Pada tahap ini juga peneliti menentukan indikator pembelajaran, tujuan pembelajaran dan materi yang akan dicapai maupun disampaikan. 2) Menyusun perangkat pembelajaran yaitu silabus pembelajaran dan RPP (Rencana Pelaksanaan Pembelajaran) siklus II. 3) Menyusun lembar kegiatan siswa yang akan digunakan pada saat proses pembelajaran berlangsung. 4) Menyusun alat evaluasi berupa tes tertulis untuk mengetahui hasil belajar siswa. 5) Merancang lembar observasi yang akan digunakan untuk mengobservasi kegiatan pembelajaran. Peneliti membuat lembar observasi aktivitas guru dan siswa selama proses pembelajaran.

Pelaksanaan tindakan dan observasi pada siklus II dilaksanakan pada hari kamis, 04 April 2019 dengan alokasi waktu 2 x 35 menit. Pada pelaksanaan siklus II, peneliti akan melaksanakan sesuai dengan RPP dan kegiatan aktivitas guru dalam proses pembelajaran tematik melalui metode outdoor study berbasis scientific learning.

Pada kegiatan awal, guru mengawali kegiatan pembelajaran dengan mengucapkan salam. Setelah itu guru mengkondisikan kelas dengan mengajak siswa melakukan ice breaking untuk siswa berkonsentrasi sebelum dimulainya pembelajaran. Kemudian dilakukan dengan kegiatan apersepsi tujuannya untuk memacu interaksi antara guru dan siswa serta mengetahui pengetahuan awal yang dimiliki siswa. Pada kegiatan ini terdapat respon positif dari siswa, pada saat guru memberikan stimulus berupa pertanyaan, terlihat sudah hampir semua siswa dapat menjawab pertanyaan. Setelah itu guru menyampaikan tujuan pembelajaran.

Guru membahas tema 8 daerah tempat tinggalku pada subtema 3 pembelajaran 4. Sedangkan pada kegiatan inti pembelajaran meliputi kegiatan mengamati, menanya, menalar, mengumpulkan informasi, dan mengkomunikasikan. Sebelum melakukan pembelajaran di luar kelas, guru menyebutkan tata tertib ketika melakukan belajar di luar kelas. Guru dan 
siswa keluar kelas bersama-sama dan mencari tempat yang nyaman untuk melakukan kegiatan proses pembelajaran.

Guru memberikan materi dengan jelas kepada siswa. Kemudian guru melakukan tanya jawab dengan siswa tentang penokohan. Setelah itu guru membagi kelompok ke dalam 4 kelompok yang terdiri dari 5 orang, kemudian guru menjelaskan cara mengerjakan tugas. Setiap kelompok membuat sebuah cerita fiksi dengan mengamati lingkungan sekolah sehingga setiap kelompok akan menemukan ide untuk membuat sebuah cerita.

Setelah semua siswa rapih dalam membuat lingkaran di sebuah taman sekolah guru menyampaikan materi tentang kegiatan ekonomi dalam mata pencaharian. Guru memberikan LKS (Lembar Kegiatan Siswa) dan menjelaskan cara mengerjakannya. Kemudian guru membimbing kegiatan diskusi siswa. Siswa diminta untuk mengumpulkan informasi dan menyelesaikan LKS tersebut. Setiap kelompok diharapkan untuk bekerja sama dalam mengerjakan LKS (mengasosiasi). Setelah selesai, setiap kelompok untuk mengkomunikasikan hasil diskusinya di depan teman-teman semua. Kelompok yang belum membacakan hasilnya diharapkan untuk mendengarkan temannya yang sedang menyampaikan hasil diskusinya.

Pada akhir pembelajaran, guru melakukan tes evaluasi terhadap siswa. Pada tes ini setiap siswa menjawab 5 butir soal yang diberikan oleh guru secara individu. Kemudian guru menyimpulkan apa yang telah dipelajari. Guru mengucapkan salam dan menutup pembelajaran dengan mengucapkan hamdalah.

Hasil belajar siswa pada pembelajaran tematik melalui metode outdoor study berbasis scientific learning pada siklus II dari 21 siswa diperoleh data 18 siswa yang tuntas melebihi nilai KKM dan 3 siswa nilainya masih dibawah nilai KKM. Dari pelaksanaan siklus II tersebut, diperoleh nilai tertinggi yaitu 96 dan nilai terendah yaitu 50. Dan diperoleh nilai rata-rata yaitu 84,38. Maka dapat disimpulkan bahwa hasil belajar siswa siklus II dapat dikatakan berhasil sebesar $85,71 \%$.

Kegiatan observasi pada siklus II dilakukan untuk mengumpulkan data mengenai aktivitas guru maupun siswa dalam proses pembelajaran. Hasil observasi aktivitas guru selama proses pembelajaran mencapai persentase yaitu $83,75 \%$. Dan hasil observasi aktivitas siswa selama proses pembelajaran berlangsung mencapai persentase yaitu $82,14 \%$.

Caruban : Jurnal Ilmiah Pendidikan Dasar 2(1), 40-52, Januari 2019

p-ISSN 2615-1391, e-ISSN 2620-3219 @Prodi PGSD Universitas Swadaya Gunung Jati 
Hal ini menunjukkan bahwa penerapan metode outdoor study berbasis scientific learning, hasil observasi aktivitas guru maupun siswa, dan hasil belajar siswa mencapai target dan dianggap berhasil. Sehingga penelitian cukup sampai siklus II dan tidak dilanjutkan pada penelitian siklus berikutnya.

Pada pembahasan hasil penelitian akan dianalisis peningkatan hasil belajar dalam pembelajaran siklus I dan siklus II dengan menerapkan metode outdoor study berbasis scientific learning. Berikut ini merupakan data hasil belajar siswa dalam pembelajaran tematik selama dua siklus :

Tabel 1. Hasil Belajar Siswa

\begin{tabular}{llll}
\hline & Prasiklus & Siklus I & Siklus II \\
\hline Nilai Terendah & 45 & 50 & 50 \\
Nilai Tertinggi & 100 & 90 & 96 \\
Rata-Rata & 69,76 & 70,48 & 84,38 \\
Persentase & $42,86 \%$ & $52,38 \%$ & $85,71 \%$ \\
\hline
\end{tabular}

Sumber: Data Penelitian, 2019

Hasil belajar siswa mengalami peningkatan terlihat dari tabel 1 diatas adalah pada prasiklus $42,86 \%$, siklus I peneliti menggunakan metode outdoor study berbasis scientific learning kemudian mengalami perubahan hasil belajar mendapatkan persentase 52,38\%, dan pada siklus II peneliti masih menggunakan metode outdoor study berbasis scientific learning dengan sedikit perubahan dalam proses pembelajaran sehingga hasil belajar siswa meningkat hingga persentase hasil belajar mencapai 85,71\%.

Hal ini dapat dikatakan berhasil apabila seseorang berhasil atau tidak mengalami suatu proses belajar, dapat diukur oleh hasil belajar. Menurut K. Brahim dalam Susanto (2013: 5) menyatakan bahwa "hasil belajar dapat diartikan sebagai tingkat keberhasilan siswa dalam mempelajari materi pelajaran di sekolah yang dinyatakan dalam skor yang diperoleh dari hasil tes mengenal sejumlah materi pelajaran tertentu".

Dalam pembelajaran tematik ini dapat meningkatkan hasil belajar siswa, karena dalam pembelajaran tematik lebih menekankan pada keterlibatan siswa dalam proses pembelajaran, sehingga siswa dapat memperoleh pengalaman langsung dan terlatih untuk dapat menemukan sendiri berbagai pengetahuan yang dipelajarinya. Seperti yang telah dipaparkan oleh Trianto (2011: 147) bahwa pembelajaran tematik pada dasarnya adalah model pembelajaran terpadu yang menggunakan tema 
untuk mengaitkan beberapa mata pelajaran sehingga dapat memberikan pengalaman bermakna kepada siswa.

Hal ini sejalan dengan yang dikemukakan Hosnan (2014:13) pendekatan saintifik mendekatkan kemampuan intelek peserta didik sehingga mudah memahami materi yang dipelajari. Pendekatan saintifik mengembangkan karakter peserta didik, sehingga peserta didik mudah menerima perbedaan sosial diantara mereka, apabila ada yang melakukan kesalahan, peserta didik dapat dengan mudah menyesuaikan diri dengan mengucapkan permintaan maaf.

Berdasarkan pembahasan di atas mengenai hasil penelitian yang telah diuraikan maka target yang ditentukan oleh peneliti telah mencapai untuk peningkatan hasil pembelajaran tematik siswa kelas IV melalui metode outdoor study berbasis scientific learning yang telah tercapai pada siklus II dan termasuk ke dalam kategori sangat baik.

\section{Simpulan}

Penggunaan metode outdoor study berbasis scientific learning pada pembelajaran tematik dapat meningkatkan aktivitas pembelajaran. Hal ini dapat dilihat dari ketercapaian pada siklus I yang memperoleh hasil observasi aktivitas guru $70 \%$ sedangkan hasil observasi aktivitas siswa mencapai $67,85 \%$. Sedangkan pada siklus II hasil observasi aktivitas guru mencapai 83,75\% dan hasil observasi aktivitas siswa mencapai 82, 14\%.

Hasil belajar yang diperoleh siswa dengan menggunakan metode outdoor study berbasis scientific learning pada pembelajaran tematik dapat meningkat. Hal ini dapat dilihat dari hasil belajar siswa yang tuntas pada siklus I sebanyak 52,38\% dengan nilai rata-rata yaitu 70,48. Sedangkan pada siklus II mengalami peningkatan menjadi $85,71 \%$ dengan nilai rata-rata 84 , $38 \%$. Peningkatan tersebut dapat disimpulkan bahwa penelitian mengalami keberhasilan.

\section{Daftar Pustaka}

Asmahasanah, Salati, dkk. (2018). Analysis of The Role of Higher Education in The Development of Pedagogic Competence of Madrasah Teachers Through The Learning of School Garden. Proceedings of International Conference, $\begin{array}{llll}\text { Paper } & \text { No. 241-248. Online) }\end{array}$ http://jurnal.unissula.ac.id/index.php/bksptis/article/view/3578 
Asmahasanah, Salati, dkk. (2018). Pembelajaran Berbasis Lingkungan $\mathcal{E}$ Sociopreneur (Analisis Praktik Nilai Sosial, Entrepreneur, dan Religius). Bogor: UIKA PRESS.

Danim, Sudarwan. (2013). Pengantar Kependidikan, Bandung: ALFABETA.

Hosnan, M. (2014). Pendekatan Saintifik dan Kontekstual dalam Pembelajaran Abad 21. Bogor: Penerbit Ghalia Indonesia.

Kunandar. (2016). Langkah Mudah Penelitian Tindakan Kelas Sebagai Pengembangan Profesi Guru. Jakarta: PT RajaGrafindo Persada.

Majid, Abdul. (2017). Pembelajaran Tematik Terpadu. Bandung: PT Remaja Rosdakarya.

Mulyasa. (2014). Guru dalam Implementasi Kurikulum 2013. Bandung: PT Remaja Rosdakarya.

Sudijono, Anas. (2017). Pengantar Statistik Pendidikan. Jakarta: PT RajaGrafindo Persada.

Susanto, Ahmad. (2013). Teori Belajar dan Pembelajaran di Sekolah Dasar. Jakarta: Kencana.

Tampubolon, Saur. (2014). Penelitian Tindakan Kelas. Jakarta: PT. Gelora Aksara Pratama.

Trianto. (2011). Desain Pengembangan Pembelajaran Tematik Bagi Anak Usia Dini TK/RA \& Anak Usia Kelas Awal SD/MI. Jakarta: Kencana. 